\title{
Patient safety with mental disorder: developing management technologies for risk management ${ }^{a}$
}

\author{
Segurança do paciente com transtorno mental: elaboração de tecnologias gerenciais para a \\ gestão de riscos

\section{Seguridad del paciente con trastorno mental: elaboración de tecnologías gerenciales para la} \\ gestión de riesgos
}

Fernanda Cordeiro Sirtoli Vantil ${ }^{1}$ (D) Eliane de Fátima Almeida Lima $^{1}$ (C) Karla Crozeta Figueiredo ${ }^{2}$ (1) Flávia Batista Portugual ${ }^{1}(\mathbb{C})$ Ana Inês Sousa ${ }^{3}$ Cândida Caniçali Primo ${ }^{1}$

1. Universidade Federal do Espírito Santo. Vitória, ES, Brasil.

2. Universidade Federal do Paraná.

Curitiba, PR, Brasil.

3. Universidade Federal do Rio de Janeiro. Rio de Janeiro, RJ, Brasil.

\begin{abstract}
Objective: To describe the development of management technologies for risk management in the safety of patients with mental disorders. Method: A research study, conducted in 17 seminars with 13 members of the multiprofessional team from a reference hospital in mental health in a state in the southeastern region of Brazil. Results: Two management technologies were developed and validated: Risk management diagram and protocols, both focusing on the safety of patients with mental disorders. Conclusions and implications for practice: The safety protocol of the patient with a mental disorder and the diagram in a tree of risk management were two management technologies constructed in this study. Both can offer the nurse and multidisciplinary team a baseline to qualified care, grounded in patient safety principles.
\end{abstract}

Keywords: Patient Safety; Mental Disorders; Risk Management; Technology.

\section{Resumo}

Objetivo: Descrever a elaboração de tecnologias gerenciais para a gestão de riscos na segurança do paciente com transtorno mental. Método: Estudo do tipo pesquisa-ação, realizado em 17 seminários com 13 integrantes da equipe multiprofissional de um hospital de referência em saúde mental, em um estado da região Sudeste do Brasil. Resultados: Foram elaboradas e validadas duas tecnologias gerenciais: Diagrama da gestão de risco e protocolos, ambos com enfoque na segurança do paciente com transtorno mental. Conclusões e implicações para a prática: $O$ protocolo de segurança do paciente com transtorno mental e o diagrama em árvore de gestão de riscos foram as duas tecnologias gerenciais construídas neste estudo. Ambos podem oferecer ao enfermeiro e a equipe multidisciplinar uma linha de base para o cuidado qualificado, fundamentado nos princípios de segurança do paciente.

Palavras-chave: Segurança do Paciente; Transtornos Mentais; Gestão de Riscos; Tecnologia.

\section{Resumen}

Objetivo: Describir la elaboración de tecnologías gerenciales para la gestión de riesgos en la seguridad del paciente con trastorno mental. Método: Estudio del tipo investigación acción, realizado en 17 seminarios con 13 integrantes del equipo multiprofesional de un hospital de referencia en salud mental en un estado de la región sudeste de Brasil. Resultados: Se elaboraron y validaron dos tecnologías gerenciales: diagrama de gestión de riesgos y protocolos, ambos con enfoque en la seguridad del paciente con trastorno mental. Conclusiones e implicaciones para la práctica: El protocolo de seguridad del paciente con trastorno mental y diagrama en árbol de la gestión de riesgo, fueron las dos tecnologías gerenciales construidas en este estudio. Ambas pueden ofrecer al enfermero y al equipo multidisciplinar una línea de base para el cuidado cualificado, fundamentado en principios de seguridad del paciente.

Palabras clave: Seguridad del Paciente; Trastornos Mentales; Gestión de Riesgos; Tecnología.
Corresponding author:

Eliane de Fátima Almeida Lima.

E-mail: elianelima66@gmail.com

Submitted on $04 / 25 / 2018$

Accepted on 06/24/2018.

DOI: 10.1590/2177-9465-EAN-2017-0307 


\section{INTRODUCTION}

Mental health patient has particularities in his psychic state. Such characteristics can be predisponded of some risk behaviors, such as suicide, violence and self-aggretion, influencing on safety to the patient and those around him. ${ }^{1}$ This way, it is necessary that mental health patient care, beyond care aready applied to the clinical patient referred to organic condition, attention to possible predisponded to situations that can be harmful to the patient or to the team that assist him. ${ }^{2}$

According to Brazilian Norm ISO $31000: 2009,{ }^{3}$ Risk Management is the systematization and application of policies, procedures and practices for the identification, evaluation, treatment, monitoring and critical analysis of risks related to health care.

In patient safety, risk management aims at the early identification of potential risks, and, consequently, to reduce or eliminate adverse effects resulting from health care. There should be guarantees by the risk manager that the prevention, detection, recording and correction of deficiencies should be carried out, and it is necessary to insert strategies for change in the culture of fault detection, subsidizing professionals in the prevention of errors by measures to ensure the quality of the. ${ }^{4}$

Such strategies for risk management are supported by technologies that emerge from experiences, experiences and research, which allows the concretization and construction of products with the purpose of intervening in a certain practical situation. In nursing, the technologies are classified in: educational, care and management. Education refers to the tools for the teaching-learning process, used by educators and learners, and can be used in the various processes of academic and continuing education. Assistive technologies are the devices used to mediate processes involving care, applied by professionals with patients in health services. And the managerial technologies are those for the mediation of management processes, applied by professionals in the health services. ${ }^{5}$

So that risk management is implemented, Brazilian Norm ISO 31000:2009 stabilishes that some aspects are considered, among them the use of tools to manage risks, ${ }^{3}$ as the diagram in a tree, that enables to identify details or unfolding an action, isses to be studied. It aims to demonstrate the steps of actions and goals that must be fulfilled to achieve the primary goal. Its name "tree" is explained by the fact that its structure has ramifications, which unfold from the objective (or end) to the tasks (or means) that will be developed. For an even more detailed planning, it is suggested to create a matrix for control in each task, containing the items who, when and status. ${ }^{6}$

In this context, another important instrument for management is the protocols, which are a set of rules, norms or standards, with the objective of standardizing a conduct and facilitating the management of actions. ${ }^{7}$ Protocols can be clinical and/or organization of services, when classified according to their nature. ${ }^{8}$ Its use allows greater safety to users and professionals, directing them to decision making and incorporation of new technologies, minimizing the variability of care actions, innovation of care, rational use of available resources and consequent transparency and cost control. In addition, the protocols facilitate the development and monitoring of indicators and process quality. ${ }^{9}$

For the elaboration of a protocol, it is necessary the team work, knowledge of the population that will be assisted and resources. Next, it is necessary to adapt it to the reality of the territory, to know the forms of organization of the local society or, in the case of a hospital institution, to define the priorities, needs, to know the epidemiological profile of the events and situations that are desired standardize with protocols; including recognizing the areas of risk and who is most exposed to those risks. ${ }^{8,10}$

In view of the above, the following questions are raised: 1) Management technologies, including service organization protocols and risk management tree diagram, are important tools for risk management in patient safety; 2) The theme of risk management in patient safety is something that is emerging and needs to be discussed and implemented in institutions; 3) Mental health patients safety has some specific characteristics that should be considered for risk management.

In this sense, this article aims to describe the development of management technologies for risk management in the safety of patients with mental disorders.

\section{METHOD}

Research-action study, developed with all members of a multiprofessional team of mental health reference hospital in the southeast of Brazil. 13 participants were devided in two groups, being one of six members and the other of seven. Each group participated in eight meetings, which identification of priorities and of risk fctors that involve the mental health patient safety were developed. Afterwards, there was the definition of protocol structure (which would be the document component).

Based on international patient safety goals and institution's reality, seven mental health patient safety priorities were elected: patient correct identification; hand hygiene; violence prevention; safe medication prescription and administration; patients' evasion prevention; prevention of Restraint injury; fall prevention.

Subsequently, the elaboration of the protocols started. In the meeting, the discussed subject was analysed and formated in the protocol pattern defined by the group and delivered by participants for evaluation and suggestions. In the following meeting consensual validation was developed. For the validation, $100 \%$ agreement among the participants was considered, and items that did not reach consensus were 
adjusted to the agreement of all participants. Following, activities regarding protocol ellaboration and validation of each meeting are described:

In the meeting 1, priorities were defined based on reality, having patient safety protocol ellaborated: fall prevention; evasion prevention; patient correct identification; prevention of mechanical restraint injury; hand hygiene; and correct medication prescription and administration and violence prevention.

In the meeting 2, there was the definition of protocol components pattern; goal; comprehensiveness; risk factors; prevention measures; how to proceed if the situation occurs; event notification; indicators, and the discussion to elaborate the fall prevention protocol.

In the meeting 3, fall prevention protocol consensus validation and discusssion to ellaborate evasion prevention protocol followed. In the meeting 4, evasion prevention consensual protocol validation and discussion for ellaboration of patient correct identification were carried out.

In the meeting 5, there was the consensual validation of patient correct identification protocol and discussion to elaborate protocol for prevention of mechanical restraint injury. In the meeting 6, consensual validation of the protocol for the prevention of mechanical restraint injury and promoted the discussion to elaborate the hand hygiene protocol.

In the meeting 7 , consensual validation of the hand hygiene protocol and the discussion to elaborate the protocol of prescription and correct medication administration were carried out. In the meeting 8 , consensual validation of the protocol for the prevention of correct prescription and administration of medication, elaboration of the protocol for the prevention of violence, and consensual validation of the protocol for the prevention of violence.

Subsequent to content analysis ${ }^{11}$ of group discussions and the $8^{\text {th }}$ meeting, the risk management tree diagram in mental health patients' safety was developed graphically: in the first column, each stage of risk management was deployed to the second column, in which the corresponding actions were described and, in the third column, a description of the indicators that will be monitored. In observation boxes, the control matrix. The finished diagram was presented at the last meeting - the $9^{\text {th }}$ seminar, which gather all 13 participants, in which there was the study's participants' evaluation and validation through consensus of tree diagram. In addition, in this seminar all the protocols duly formatted and validated by consensus were presented by the group.

The present work respected the ethical principles regarding research with human beings, being appreciated and approved by the Research Ethics Committee, receiving the Feedback of no 1.634.031, CAAE 53621716.5.0000.5060.

\section{RESULTS}

Two management technologies were elaborated: protocols and tree diagram of risk management of mental health patient safety.

\section{Mental health patient safety protocol description}

Management technology denominated patient safety protocols, constituted by seven protocols, which are: Patient Correct Identification; Hand Hygiene; Violance Prevention and Safe Medication Administration; Patient Evasion Prevention; Preventing Restraint Injury; Fall Prevention.

Protocols have a standardized formatting, present an identification header and footnotes with data about the version and date, document elaboration and approval. Each protocol has a component sequency: definition, goal, comprehensiveness, risk factors, prevention measures, how to proceed (in the specific case of each protocol, for exemple on patient evasion, fall, among others), notification, indicators and references. On Figure 1, an elaborate protocol example is presented.

Figure 1. Built protocol sample. Brazil, 2017.

RISK MANAGEMENT ONMENTAL HEALTH PATIENT SAFETY

\begin{tabular}{l|l} 
Patient safety protocol & Technical team:
\end{tabular}

PATIENT EVASION PREVENTION

PATIENT EVASIONDEFINITION

PATIENT EVASION PREVENTION PROTOCOL GOAI :

PATIENT EVASION PREVENTION PROTOCOL COMPRE HENSIVENESS:

PATIENT EVASIONRISK FACTORS

Related to the individual with mental disorder

Related to the hospital envirornment

PATIENT EVASION PREVENSION MEASURES

HOW TOPROCEED IN STUATIONS OF PATIENTEV ASION

EVASION NOTIFICATION

REFERENCES

Elaborated by a multiprofessional team

\section{Version 01: Da}

Technical administration

\section{Mental health patient safety risk management tree diagram description}

Management technology denominated tree diagram, that presented sistematically the management steps for the mental health patient safety, which are: risk identification, risk analysis, risk evaluation and risk treatment. Each step unfolds in actions that should be developed to reach patient safety, and, for once, each action has a control matrix that specifies who, when and if it's concluded or not.

This way, in the first step, risk recognition, actions are to analyze the institutional context and the patients' profile and define risk priorities that should be controled; on the second step, risk analysis, actions are to develop and implement patient safety protocols; on the third step, risk evaluation, actions to monitor patient safety indicators and to investigate adverse events or notified Near Miss. 
On the third step, it's emphasized that the first action, to monitor indicators, unfolds in which indicators will be monitored: number of physical violence with damange; number of sexual violence; number of patient evasion; number of falls with damage; numbers of falls without damage; fall rate (number of falls/ number of patients-day) $\times 1000$; number of lesion (wound or trauma) for mechanic restraint; number of adverse events due to erros in medication prescription and administration; number of adverse events due to faults on patient identification; adherence percentage (\%): number of hand hygiene actions developed by health professionals/number of opportunities occured to hnd hygiene, multiplied by 100 .

On the last step, risk treatment, there is the evaluation and revision of the whole process. As for control matrix, thr first three mentioned actions were developed by a multiprofessional team, during this research and the concluded situation. As to other four actions, they will developed by the institution's Patient Safety Nucleus, after nomination in Official Journal; this way, these actions' situations are still not concluded. On Figure 2, it is observed the mental health patient safety management risk tree diagram.

\section{DISCUSSION}

Several management technologies can contribute to the management process and quality: afinity diagram; relationship diagram; tree diagram; decision matrix; stratification; decision process diagram; relationship matrix; verification sheet; graphics; cause and effect diagram; relationship diagram; histogram; scatter diagram; Flowchart; Brainstorming; $5 \mathrm{~W} 1 \mathrm{H}$; PDCA; Protocols, among others. ${ }^{6}$

Management instruments that standardize procedures have been widely elaborated in nursing. Researches point out that protocols contribute so that all professionals provide a standardized care following technical scientifical principals, support nurse's decision making process, enable adjust non conformities, and still, develop a teaching goal. In addition, the use of protocols allows greater security in the execution of the procedures, provides greater satisfaction for the nursing team and the patient, and, lastly, greater quality and safety in care. $^{9,10,12,13}$

Tools built in this research are strategies for patient safety management risk, in which the participation of the whole team is necessary - from managers to activities executors --, because it assures that risk management reaches local issues, of angles and strategic positions. ${ }^{3,10}$

Although patient safety is a topic widely discussed today, his discussion on mental health is still restricted. ${ }^{1}$ This way, management Technologies that enable the viability of risk managements inherents to the patient with mental disorder should be developed and applied aiming a damage free care..$^{1,2}$

Figure 2. Mental health patient safety management risk tree diagram. Brazil, 2017. Source: Created by Vantil, Lima, Primo. 2017.

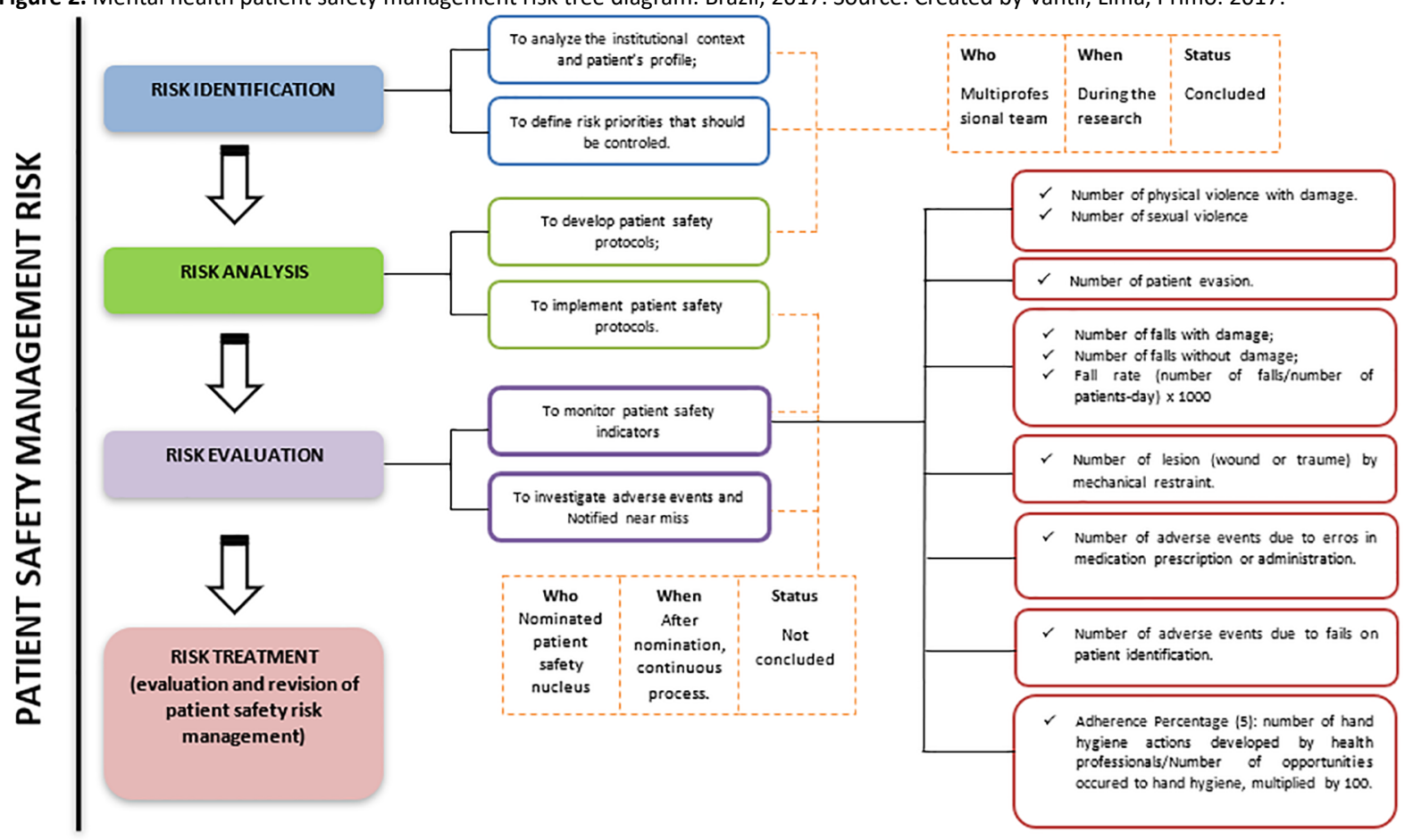




\section{CONCLUSIONS AND IMPLICATIONS FOR PRACTICE}

Technology use to health care enables advances of practices and the improvement of provided care. Regarding the mental health patient safety, it's a fact that the thematic needs to be widely discussed, given the specificity of the public attended and the innumerable particularities and predisposing factors that can cause harm to the patient.

Management technologies construction - in the case of this study, mental health patient safety and risk management tree diagram - offers the nurse and the multidisciplinary team a base line so that care is offerted with quality, fundamented in patient safety principals.

\section{REFERENCES}

1. Rocha EKS, Loyola CMD. Administration of medication to use when needed and the care of psychiatric nursing. Rev Bras Enferm [Internet]. 2014 Jul/Aug; [cited 2016 Jul 13]; 67(4):563-7. Available from: http://www.scielo.br/scielo.php?script=sci_arttext\&pid=S003471672014000400563\&Ing=en. DOI: http://dx.doi.org/10.1590/00347167.2014670410

2. Briner M, Manser T. Clinical risk management in mental health: a qualitative study of main risks and related organizational management practices. BMC Health Serv Res [Internet]. 2013 Feb; [cited $2016 \mathrm{Jul}$ 13]; 13:44. Available from: https://bmchealthservres.biomedcentral.com/ articles/10.1186/1472-6963-13-44

3. Associação Brasileira de Normas Técnicas (ABNT). ABNT NBR ISO 31000 - Gestão de riscos. Princípios e diretrizes. 30 de novembro de 2009. $1^{\text {a }}$ ed. [Internet]. [cited 2017 Jul 12]. Available from: https:// gestravp.files.wordpress.com/2013/06/iso31000-gestc3a3o-de-riscos. pdf

4. Fernandes LGG, Tourinho FSV, Souza NL, Menezes RMP. Contribuição de James Reason para a segurança do paciente: reflexão para a prática de enfermagem. Rev Enferm UFPE On Line (Recife) [Internet]. 2014 Jul; [cited 2017 Jul 12]; 8(Supl. 1):2507-12. Available from: https://periodicos. ufpe.br/revistas/revistaenfermagem/article/viewFile/9944/10252
5. Nietsche EA, Backes VMS, Colomé CLM, Ceratti RN, Ferraz F Tecnologias educacionais, assistenciais e gerenciais: uma reflexão a partir da concepção dos docentes de enfermagem. Rev Lat Am Enferm [Internet]. 2005 May/Jun; [cited 2017 Jun 18]; 13(3):344-52. Available from: http://www.scielo.br/scielo.php?script=sci_arttext\&pid=S0104$11692005000300009 \&$ Ing $=$ en

6. César FIG. Ferramentas Básicas da Qualidade: Instrumentos para Gerenciamento de Processo e Melhoria Contínua. $1^{\text {a }}$ ed. São Paulo: Biblioteca 24 horas; 2013. 132 p. [Internet]. [cited 2016 Jul 13]. Available from: https:// books.google.com.br/books/about/Ferramentas_B\%C3\%A1sicas_da Qualidade.html?hl=pt-BR\&id=CniEMu69GTgC

7. Conselho Regional de Enfermagem de São Paulo (CORENSP). Guia para a Construção de Protocolos Assistenciais de Enfermagem. 1 ${ }^{\text {a }}$ ed. São Paulo: CORENSP; 2017. 49 p. [Internet]. [cited 2018 May 22]. Available from: http://portal.coren-sp.gov.br/sites/default/files/Protocolo-web.pdf

8. Wernek MAF, Faria HP, Campos KFC. Protocolos de cuidado à saúde e de organização do serviço. Nescon (Núcleo de educação em saúde coletiva). Belo Horizonte: Faculdade de Medicina da Universidade Federal de Minas Gerais-UFMG; 2009. 84 p. [Internet]. [cited $2016 \mathrm{Ju}$ 13]. Available from: https://www.nescon.medicina.ufmg.br/biblioteca/ imagem/1750.pdf

9. Sales CB, Bernardes A, Gabriel CS, Brito MFP, Moura AA, Zanetti ACB Standard Operational Protocols in professional nursing practice: use, weaknesses and potentialities. Rev Bras Enferm [Internet]. 2018; [cited 2018 May 22]; 71(1):126-34. Available from: http://www.scielo.br/pdf/ reben/v71n1/0034-7167-reben-71-01-0126.pdf

10. Nicolini AB, Corrêa ACP, Medeiros RMK, Fraga JCAXO, Silva LA Alvares AS. Processo de elaboração de protocolo para assistência humanizada de enfermagem ao parto de risco habitual. Ciênc Cuid Saúde [Internet]. 2017 Oct/Dec; [cited 2017 Feb 12]; 16(4):1-7. Available from: http://periodicos.uem.br/ojs/index.php/CiencCuidSaude/article/ view/36841/21921

11. Bardin L. Análise de conteúdo. São Paulo: Edições 70; 2011. 229 p.

12. Nunes FDO, Barros LAA, Azevedo RM, Paiva SS. Segurança do paciente: como a enfermagem vem contribuindo para a questão? J Res Fundam Care Online [Internet]. 2014 Apr/Jun; [cited 2017 Feb 12]; 6(2):841-7. Available from: http://www.seer.unirio.br/index.php/ cuidadofundamental/article/viewFile/3007/pdf_1297

13. Miranda AL, Oliveira ALL, Nacer DT, Aguiar CAM. Resultados da implementação de um protocolo sobre a incidência de Infecção do Trato Urinário em Unidade de Terapia Intensiva. Rev Lat Am Enferm [Internet]. 2016; [cited 2017 Oct 15]; 24:e2804. Available from: http:// www.scielo.br/pdf/rlae/v24/pt 0104-1169-rlae-24-02804.pdf

a Clipping of the master's thesis "Management of risks in the safety of patients with mental disorders" presented to the Graduate Program in Nursing of the Federal University of Espírito Santo (PPGENF/UFES), 2017. 